\title{
東日本大震災津波被災漁村における復興の動向と課題
}

三陸沿岸漁村の震災以前の実態，被災・復旧状況，復興に向けた活動を対象とした広域・相対的分析

Tendency and problem on the reconstraction of the fi shery villages in the tsunami-stricken of the Great East Earthqake

Transregional and relative study Focusing on situation before and after the earthquake and reconstraction activities

\author{
大垣宏介* 斎尾直子* \\ Kosuke OHGAKI* Naoko SAIO* \\ *東京工業大学 \\ ( * Tokyo Institute of Technology)
}

\section{I 序論}

2011 年 3 月 11 日に発生した東日本大震災により大き な被害を受けた三陸沿岸地域では, 震災から 3 年以上が 経過した現在, いくつかの集落でインターネットを活用 した水産物の販売経路の拡大, 漁業体験ツアーの開催 等, 漁村復興に向けた活動が進められている。一方で, 三陸沿岸の漁業集落の多くは震災以前から漁業経営の悪 化や従事者の高齢化等, 地域の存続に関わる課題を抱え ていた。漁村復興に向けた活動の規模, 手法, 進捗状況 は，震災以前の漁業実態によっても異なってきていると 考えられる。

本研究では, 震災被害からの漁業復旧にとどまらない, インターネットを活用した水産物の販売経路の拡大, 漁 業体験ツアーの開催といった, 漁業及び漁村を震災以前 よりも良い状況にする為の復興を目指した活動を「漁業 復旧にとどまらない漁村復興に向けた活動」と設定する。 漁村復興に関する既往研究では，過去の三陸沿岸を 襲った津波被害からの漁村復興の歴史について分析をお こなった研究 (月舘 $(2012)^{1)}$ ) や行政の漁業集落復興計 画等の分析をおこなった論考 (富田 $\left.(2012)^{2)}\right)$ 等によっ て, 集落ごとに多種多様な特徵を持つ三陸沿岸部におけ る, 集落それぞれの地域性を重視した復興の重要性が明 らかにされている。また個々の漁業集落における事例 研究 (三笠 $(2012)^{3)}$ 等) も多くなされている。一方で, 漁業集落における震災以前の実態, 被災 - 復旧状況, 復 興に向けた活動について広域的かつ相対的に分析をおこ なっている研究は未だ少ない状況にある。

そこで本研究では, 三陸沿岸の被災漁村を対象とし, 震災以前の漁業実態, 被災・復旧状況, 復興に向けた活 動の動向を分析し, 漁業復旧にとどまらない漁村復興に 関しての基礎的知見を得ることを目的とする。
本研究では，青森・岩手・宮城県内の被災 29 市町村 に含まれる 95 漁業地区・476 漁業集落を研究対象とした（ 図 1)。福島県については原発事故の影響により漁業再 開の要件が異なることから本研究対象から除く。

まず 2 章では漁業センサス $2008^{7)}$ における漁業基盤 に関する 22 指標を用いたデータ分析により震災以前の 95 漁業地区の実態を把握する。また漁業経営体に関す る文献調査 ${ }^{8)}$ により, 震災による漁業の被災・復旧状 況を明らかにする。 3 章では復興に向けた活動に関する

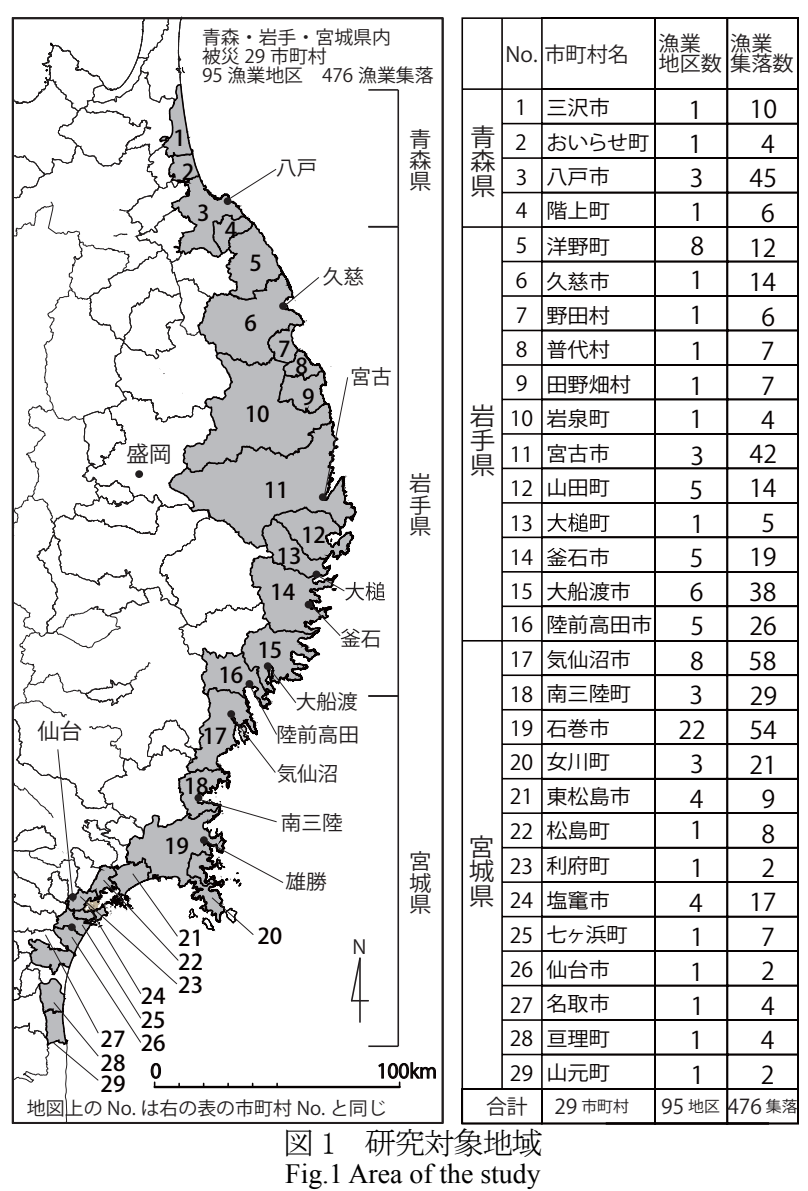


文献調查 ${ }^{10)}$ 等により抽出した活動事例 93 件を対象に活 動内容分析を行い, 漁業復旧にとどまらない漁村復興に 向けた活動の動向を把握する。 4 章では, 復興に向けた 活動がおこなわれている漁業地区の内，2 章にて明らか にした漁業基盤条件による震災以前の実態分類が異なる 2 地区にて現地調査 (参与観察) をおこない, 漁業復旧 にとどまらない漁村復興に向けた活動の実態を明らかに するとともに，今後の課題について考察をおこなう。調 査概要を表 1 , 各章における分析単位を表 2 に示す。

\section{II＼cjkstart震災以前の漁業実態及び被災・復旧状況}

\section{1 震災以前の漁業実態}

被災した漁業地区の震災以前の実態を明らかにする 為, 対象漁業集落が含まれる 95 漁業地区注 ${ }^{1)}$ を対象に, 漁業センサス 2008 における指標の中から, 漁業種類や 販売金額, 年齢別従事者数等, 漁業基盤に関する 7 指標 を選定し分析をおこなった。

まず, 指標ごとの傾向をみていく（図 2)。漁業種類別・ 経営体系別経営体数をみると, 沿岸漁業, 養殖漁業が約 $99.1 \%$ ，個人経営体が約 $95.6 \%$ を占めている。続いて販 売金額別・専兼業別経営体数をみると，全体の約 $30.5 \%$

表 1 調查概要

Table 1 Abstract of the reserch

\begin{tabular}{|c|c|}
\hline \multicolumn{2}{|c|}{ 調査 1 震災以前の漁業実態に関する調査 (2 章) } \\
\hline 方法 & データ分析 ( 主成分分析、クラスター分析 ) \\
\hline 対象 & 95 漁業地区 \\
\hline 資料 & 漁業センサス 20087)，農林水産省 \\
\hline 内容 & $\begin{array}{l}\text { 漁業経営体に関する } 22 \text { 指標 } \\
\text { (経営体系、漁業種類、販売金額、専兼業、後継者有無、従事者年齢) }\end{array}$ \\
\hline \multicolumn{2}{|r|}{ 調査 2 震災による漁業経営体の被災・復旧状況に関する調査 (2 章) } \\
\hline 方法 & 文献調査 (2013 年 11 月 ) \\
\hline 対象 & 研究対象 29 市町村内の漁業経営体 \\
\hline 資料 & $\begin{array}{l}\text { 東日本大震災による漁業経営体の被災・経営再開状況 } \\
(\mathrm{H} 23, \mathrm{H} 24, \mathrm{H} 25 \text { 年版 })^{8)} \text {,農林水産省 }\end{array}$ \\
\hline 内容 & $\begin{array}{l}\text { 震災による漁業経営体被害数、 } \\
\text { 2011.7.11、2012.3.11、2013.3.11 時点における漁業経営再開数 }\end{array}$ \\
\hline \multicolumn{2}{|r|}{ 調査 3 各市町村の水産業復興の復興プロセスに関する調査 (2 章) } \\
\hline 方法 & 文献調査 (2013 年 12 月 ) \\
\hline 資料 & 各市町村復興計画 ${ }^{9)}$, 各市町村 \\
\hline 対象 & 各市町村復興計画のうち、水産業の復興に関する部分 \\
\hline 内容 & 水産業復興期間、復興に向けた方針、施策 \\
\hline \multicolumn{2}{|c|}{ 調査 4 復興に向けた活動の動向に関する調査 (3 章) } \\
\hline 方法 & 文献調査 (2013 年 11 月 2013 年 12 月 ) \\
\hline 資料 & 各活動主体ホームページ10)等 \\
\hline 対象 & 活動事例 93 件 \\
\hline 内容 & 各活動事例について、活動内容、活動地域、活動時期等 \\
\hline \multicolumn{2}{|r|}{ 調査 5 漁業集落における復興に向けた活動の実態に関する調査 (4 章) } \\
\hline 方法 & 現地調査 (参与観察)(2013 年 8 月、11月 ) \\
\hline 対象地 & 宮城県石巻市桃浦，雄勝 \\
\hline 内容 & $\begin{array}{l}\text { 活動開始経緯、活動における漁師・外部団体等の役割、 } \\
\text { 今後の活動の展望等 }\end{array}$ \\
\hline
\end{tabular}

表 2 各章における分析単位

Table 2 Unit of analysis

\begin{tabular}{|c|c|c|c|c|c|c|}
\hline & \multicolumn{4}{|c|}{ II章 } & \multirow{2}{*}{$\begin{array}{c}\text { III章 } \\
\text { 復興に向けた } \\
\text { 活動の動向 }\end{array}$} & \multirow{2}{*}{$\begin{array}{c}\text { IV章 } \\
\text { 復興に向けた } \\
\text { 動の実態 }\end{array}$} \\
\hline & $\begin{array}{l}\text { 震星以前の } \\
\text { 態 }\end{array}$ & 被災状況 & 復旧状況 & 復興計画 & & \\
\hline \multicolumn{7}{|l|}{ 県 } \\
\hline 市町村 & & 29 市町村 & 29 市町村 & 29 市町村 & & \\
\hline 漁業地区 & 95 地区 & & & & 95 地区 & $\begin{array}{l}2 \text { 地区区口) } \\
(95 \text { 地区中) }\end{array}$ \\
\hline 漁業集落 & 476 集落 & & & & & \\
\hline
\end{tabular}

が年間販売金額 100 万円未満であり，全体の約 $70.4 \%$ が 兼業経営である。更に後継者有無別経営体数・年齢別従 事者数をみると, 約 $75.9 \%$ が後継者のいない経営体であ り，60 歳以上の従事者が約 50.5\%を占めている。

以上より, 水産庁による平成 23 年度水産白書 ${ }^{11)}$ にお いて「世界有数ともいわれる好漁場が広がっている」と いわれる三陸沿岸部においても, 震災以前から個人経営 による沿岸・養殖漁業経営体の多くが経済的に厳しい状 況にあり, 漁業従事者の高齢化・後継者不足等の課題を 抱えていたことが明らかになった。

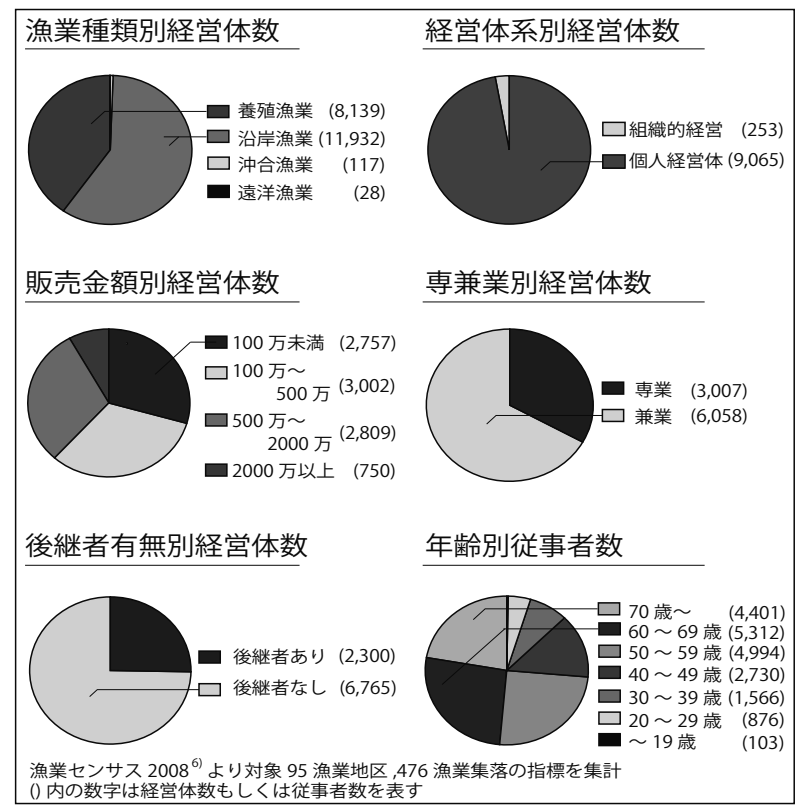

困 2 漁業基盤に関する指標の傾向

Fig.2 Tendency of indexes about fishery villages

\begin{tabular}{|c|c|}
\hline \multicolumn{2}{|c|}{ 主成分分析 } \\
\hline 分析対象 & 研究対象範囲内の 95 漁業地区 \\
\hline 入力指標 & 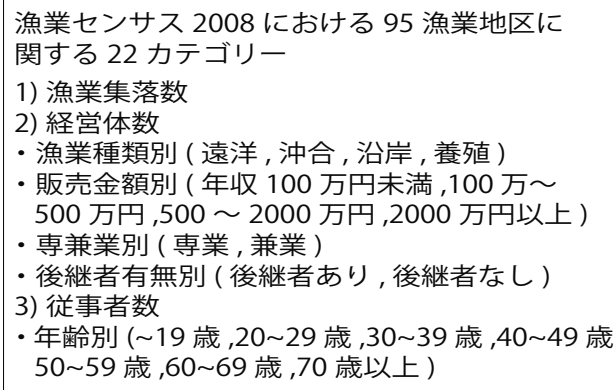 \\
\hline 採用主成分 & 主成分 1 ，主成分 2 ，主成分 3 \\
\hline 累積寄与率 & $85.20 \%$ \\
\hline
\end{tabular}

\begin{tabular}{|c|l|}
\hline \multicolumn{2}{|c|}{ クラスター分析 } \\
\hline 入力指標 & $\begin{array}{l}\text { 主成分分析における各漁業地区の主成分得点値 } \\
\text { (主成分 } 1,2,3)\end{array}$ \\
\hline 分析方法 & ウォード法 \\
\hline 類型数 & 5 類型 $(A, B, C, D, E)$ \\
\hline
\end{tabular}
漁業基盤条件による 95 漁業地区の類型化

図 3 漁業基盤条件による漁業地区の類型化の方法 Fig. 3 Method of typification of the fishery areas 
更に先に選定した各漁業地区における漁業基盤に関す る 7 指標を 22 のカテゴリーに分類し入力指標とし, 主 成分分析, クラスター分析を用いて 95 漁業地区の漁業 基盤条件による類型化をおこなった（図 3, 表 3)。

主成分負荷量プロット図をみていく（図 4)。主成分 1 は全 22 カテゴリーが+側に寄与していることから, 総 合的に漁業基盤の絶対量を表す「漁業規模」の軸である と考えられる。主成分 2 は若齢の従事者数や高額の販売 金額を有する経営体数を表すカテゴリーが＋側に寄与し ていることから, 漁業基盤の活力を示す「漁業活力」の 軸と考えられる。

更に累積寄与率が $80.0 \%$ に達する主成分 3 までの各 漁業地区の主成分得点值を入力指標としてクラスター 分析 (ウォード法) をおこなった。これより「漁業規 模」, 及び「漁業活力」の大小による漁業地区 5 類型を 得た。それらを更に,「漁業規模」「漁業活力」の大小を 総合的に表す指標「漁業体力」により, 漁業体力 5 類型 (A, B , C , D , E) に分類した（図 5) 注 2)。

震災以前の漁業体力が相対的に大きい A, B に属する漁 業地区では経営体・従事者共に多く, また高額の販売金 額を有する経営体や若い従事者も多数存在した。一方で 漁業体力が比較的小さい D, E に属する漁業地区では震災 以前から漁業規模が小さく, 従事者の高齢化率も高い状 況にあった。

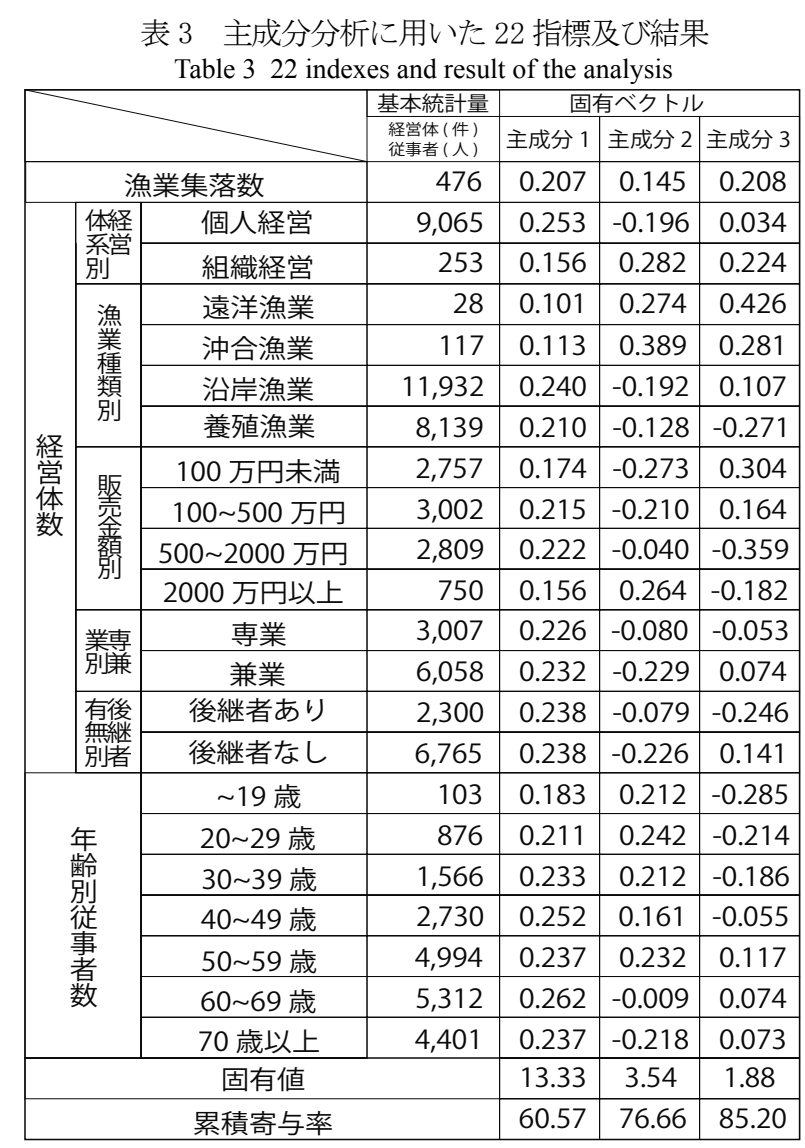

\section{2 漁業集落の被災・復旧状況}

続いて市町村ごとの漁業に関する被災状況及び漁業経 営の再開状況についてみる（図 6)。まず被災状況につ いてみていくと, 研究対象とした 29 市町村における漁 業経営体被災率注3), 漁船被苂率注4) の平均はそれぞれ約 $94.6 \%$, 約 $87.8 \%$ となっている。特に岩手県, 宮城県に おいては経営体, 漁船の被災率が共に $100 \%$ となってい る市町村も多く, 今回の震災での漁業に関する被害が広 範囲にわたって甚大であったことが分かる。震災以前の 漁業体力が相対的に小さい漁業体力類型 D, E に属する漁 業地区は震災被害によって更に厳しい状況に追い込まれ たと考えられる。

続いて震災から 4 ケ月後, 1 年後, 2 年後の 3 時点に おける被害を受けた漁業経営体の漁業経営再開率注5) を みていく。震災以前, 漁業集落数 - 経営体数の多かった 気仙沼市（58 集落・845 件）, 石巻市（54 集落・1, 290 件） では震災から 2 年後の 2013 年 3 月時点の再開率はそれ ぞれ約 $60.0 \%$ ，70.0\% となっている。また久慈市や亘理 町では 2012 年 3 月以降の漁業経営再開率の増加が止まっ てしまっている状況にある。

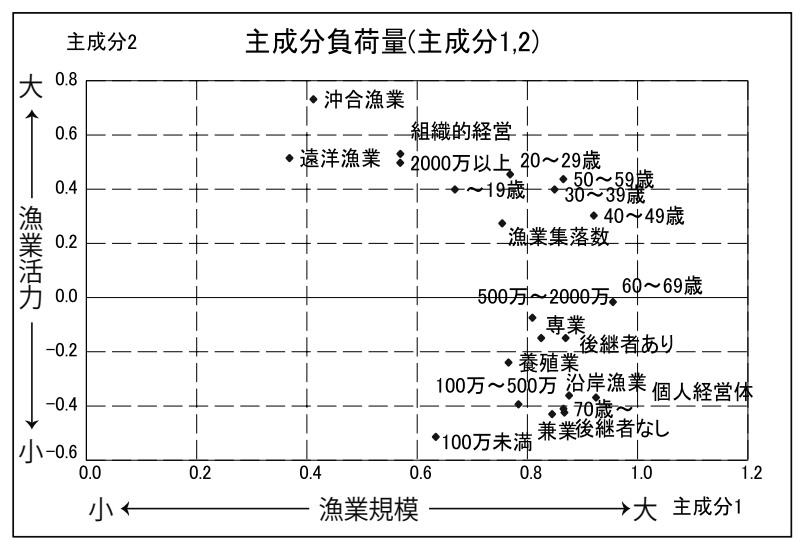

図 4 主成分負荷量プロット図

Fig.4 Scatterplot of the indexes

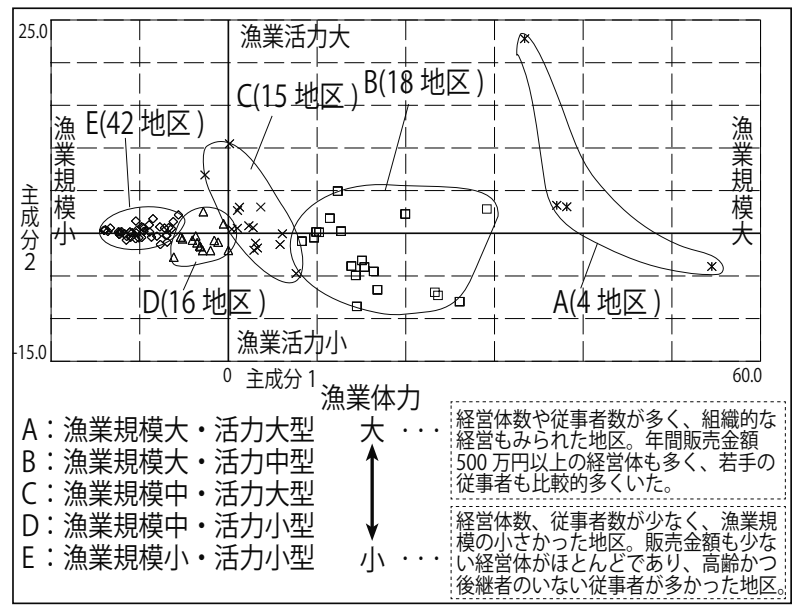

図 5 震災以前の漁業体力による漁業地区 5 類型 Fig.5 Types of the fishery areas 


\section{III 復興に向けた活動の動向}

本研究では漁業復旧にとどまらない漁村復興に向けた 活動を, 水産物のインターネット販売といった, 漁業復 興のみおこなう「漁業限定型」の活動と, 地域外から来 訪者を呼び込み地域外との交流を生み出す漁業体験ツ アーの開催といった, 漁業及び漁村復興を目指す「漁業 +漁村型」に分類し (図 7), 対象 95 漁業地区から抽出 した活動事例 93 件を対象に考察をおこなった（図 8)。

活動全体を開始時期に着目してみると，震災から約 4 ケ月後に多くの「漁業限定型」の活動が始まり，震災か ら約 1 年〜 2 年の間に多くの「漁業十漁村型」の活動が 始まっている。被災後，まずは地域の基幹産業である漁 業を再開し, その後漁業の復興を目指した活動と集落の 復興に向けた活動が融合していったと捉えられる。

各活動の地域外との関わり方をみると「漁業限定型」 の活動の多くが，震災前にはあまりみられなかった，漁 業集落特有のブランド水産物としての地域外への販売を おこない,「漁業十漁村型」の活動の多くが漁業体験ツ アーの開催等による地域外からの来訪者との交流をおこ なっている。そこで各地区内と地域外との関わり方によ る漁業地区 4 類型を設定し考察をおこなった。4 類型の

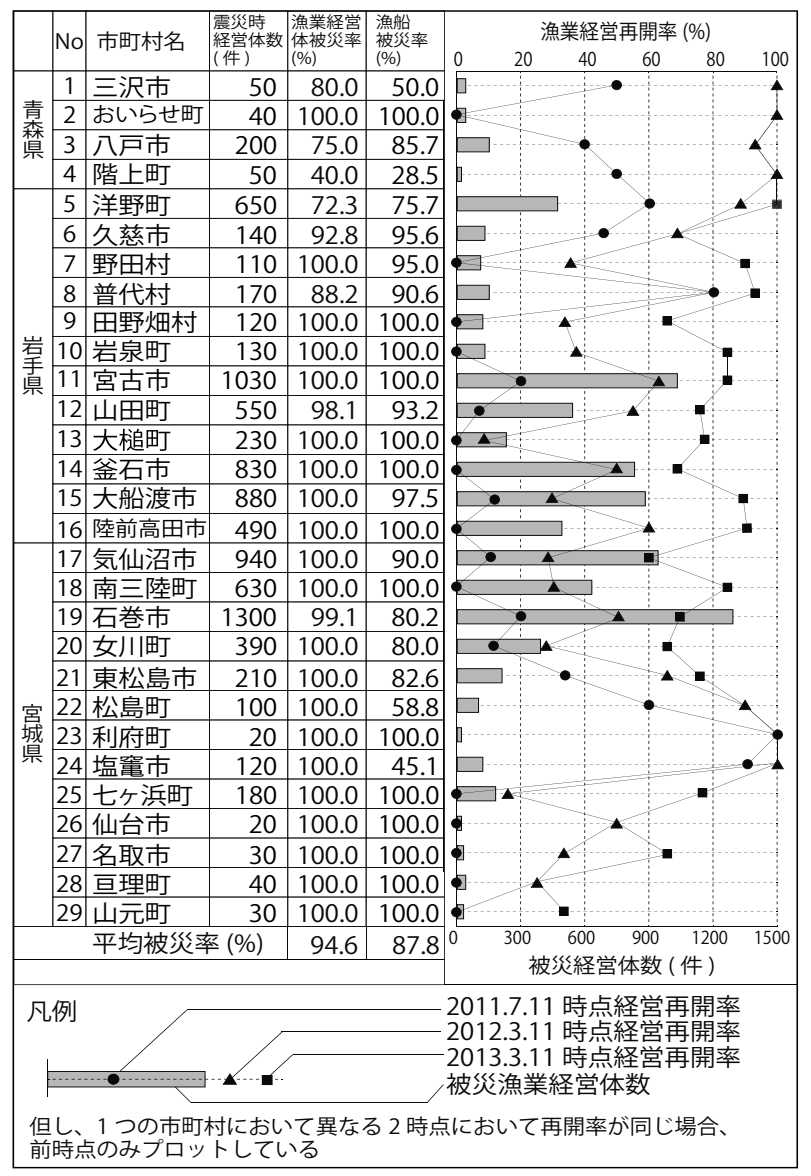

図 6 漁業に関する被災・復旧状況

Fig.6 Situation of damage and recovery
内, ii . 来訪者呼び込み型に分類される地区では地域外 からの来訪者との交流に取り組み, iii . ブランド水産物 販売型に分類される地区ではブランド水産物の地域外 の販売がおこなわれ，i . 双方向型に分類される地区で は両活動がおこなわれている。

地域外からの来訪者との交流を行っている「双方向 型」, 及び「来訪者呼び込み型」に属する地区が活動事 例の抽出された全 54 地区中 39 地区であることから， 復興に向けた活動において地域外からの来訪者との交流 を重視していることが分かる。

また「双方向型」に分類される漁業地区では,「漁業 限定型」の活動から「漁業十漁村型」の活動への発展が

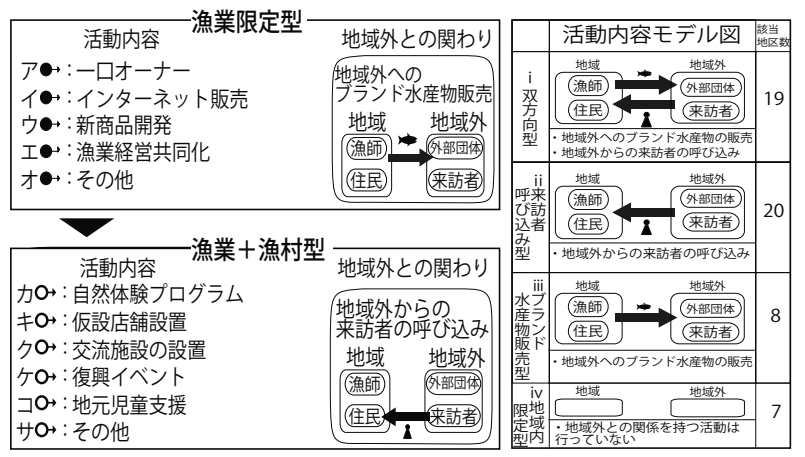

図 7 復興に向けた活動の種類

Fig.7 Types of reconstraction activities

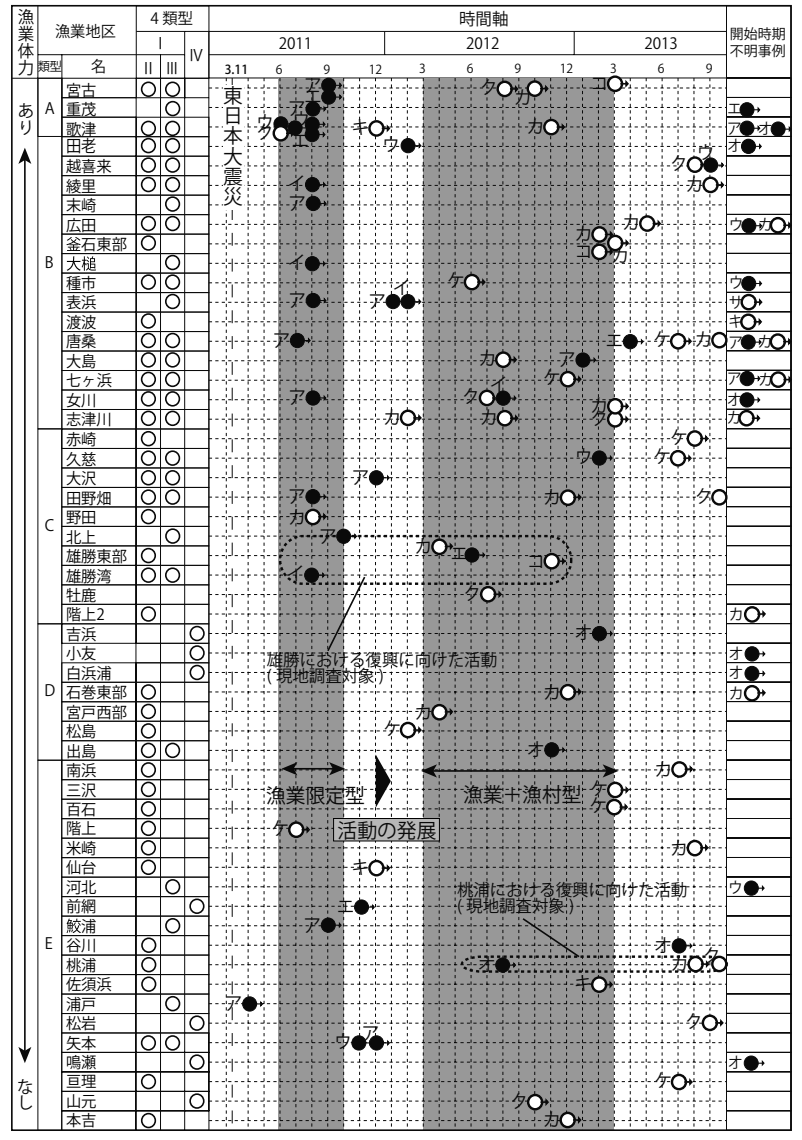

図 8 漁業地区ごとの復興に向けた活動

Fig.8 Reconstraction activity in each fishery area 
進んでいる。「双方向型」に分類される 19 地区のうち, 12 地区が, 震災以前の漁業体力が相対的に大きい漁業 体力類型 $(\mathrm{A}, \mathrm{B})$ に属している。このことから, 震災以前 の漁業体力の大小が, 地区内の復興における「漁業限定 型」の活動から「漁業十漁村型」の活動への発展の有無 に関わっている可能性が示唆される。

\section{IV 対象 2 地区における復興活動の実態と課題}

漁村復興に向けた活動の実態の詳細をみる為に, 震災 以前の漁業体力類型 $\mathrm{C}$, 類型 $\mathrm{E}$ にそれぞれ属する雄勝湾・ 雄勝東部地区 (以下「雄勝」), 桃浦地区 (以下「桃浦」)

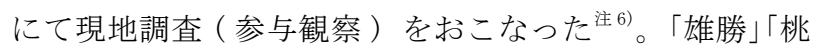
浦」は共に津波によって大きな被害を受けたが, 震災後 の復興に向けた活動において「漁業限定型」から「漁業 十漁村型」への発展がみられ, III で考察した地域外との 関わり方による 4 類型のうち, i. 双方向型に属する地 域である（図 9, 図 10)。

「雄勝」では, $15 \mathrm{~m}$ を超す津波により雄勝湾に面する 漁業集落の多くの家屋や漁港, 漁船が甚大な被害を受け た。家屋を流された人の多くは石巻市街地に建てられ た仮設住宅団地に住み, 「雄勝」の人口は震災以前の約 4,200 人から約 700 人 (2013 年 8 月時点) へと大幅に減 少している。仮設住宅に住む漁業従事者は車で片道約 45 分かけ「雄勝」へと通いながら漁業に従事している。

「雄勝」における復興に向けた活動についてみていく と, まず 2011 年 7 月から地元の漁業従事者による「漁 業限定型」の活動である雄勝産の養殖水産物の一口オー ナー制度が始まった。これはインターネットを利用して 地域外から水産業の復興資金を募り水産業復旧に役立 て, 資金提供者には水産業の復興後, 収穫した水産物に て還元する制度である。「雄勝」では一ロオーナー制度 によって集まった水産業復興資金によって, 漁具の調達 や仮設番屋の建設がおこなわれた。

その後, 震災直後から「雄勝」にて炊き出し等の復興 支援をおこない，現在も現地の古民家を拠点として様々 な復興支援をおこなっている外部団体 S と漁業従事者, 漁業従事者以外の地域住民が協力し, 2012 年 4 月から「漁 業十漁村型」の活動である, 自然体験プログラムの開催 がおこわれている。これは2001年に廃校となった地元 小学校を拠点とし漁業体験を中心とした自然体験プログ ラムを開催し, 地域外から来訪者を呼び込み, 「雄勝」 と外部との交流人口の増加を目的とした活動である。

「桃浦」も津波によって大きな被害を受け，震災以前 は 62 世帯が暮らしていたが, 震災後 3 世帯 (2014 年 4 月時点）のみとなっている。「雄勝」同様多くの漁業従
事者が石巻市街地に建てられた仮設住宅から車で片道 30 分程かけて通いながらの漁業従事となっている。

「桃浦」における復興に向けた活動についてみていく と, 2012 年夏から漁業従事者によって「漁業限定型」 の活動である漁業経営の共同化が計画され, 2013 年 9 月に県が策定した民間企業の漁業への参入を認める「水 産業復興特区」の認定をうけ地元水産物卸売会社との連 携による新たな水産物の販売経路の確保が始められた。

その後, 震災直後から桃浦を含めた牡鹿半島全体の漁 業集落で住宅再建支援等をおこなっていた地域外の大学 の建築学系研究室と漁業従事者が協力し, 2013 年 8 月 には「漁業＋漁村型」の活動である漁業体験プログラム が開催された。この活動は「雄勝」における自然体験プ ログラムと同様に, 漁業体験を通じて, 「桃浦」と地域 外との交流人口を増やし,「桃浦」への移住者や漁業の 後継者を獲得することを目的としたものである。

震災から 3 年が過ぎた現在, 「雄勝」では「漁業十漁 村型」の活動である自然体験プログラムが継続的に開催 され, 毎週末地域外から多くの学生や社会人がプログラ

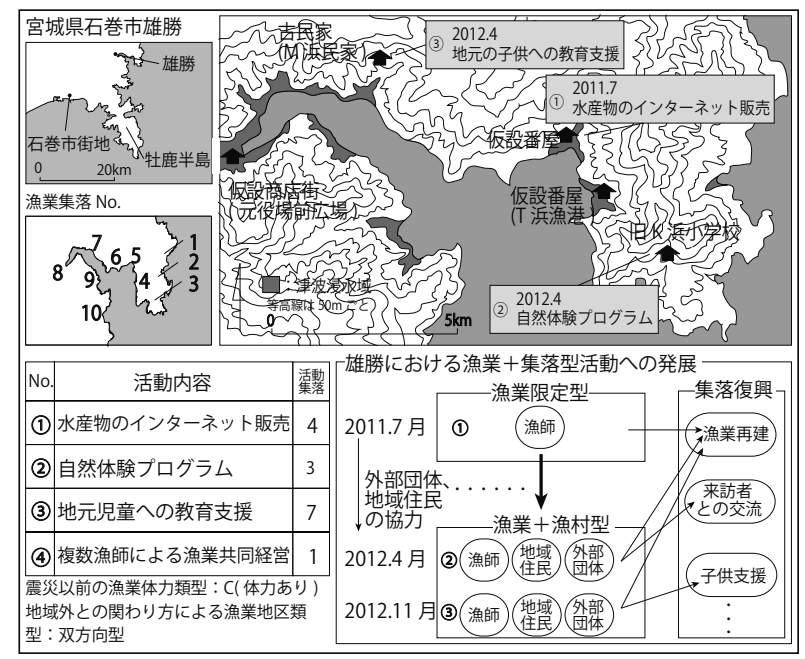

図 9 雄勝における復興に向けた活動の実態 Fig.9 Actual state of acutivities in Ogatu

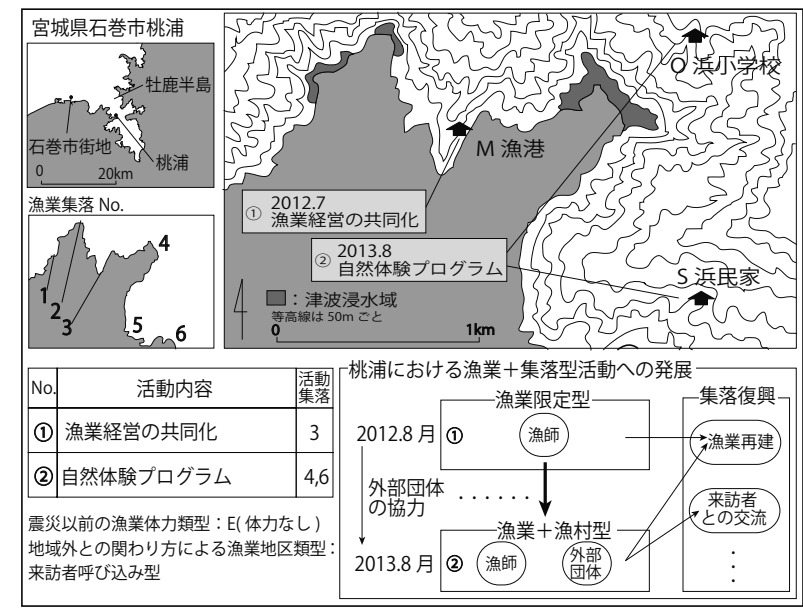

図 10 桃浦における復興に向けた活動の実態 Fig.10 Actual state of acutivities in Momonoura 
ムの参加者として雄勝を訪れるようになっている。また 2012 年 11 月から, 10 年 20 年先を見据えた活動として 地元の子供を対象とした漁業体験を含めた自然体験学習 といった教育支援が始まっている。

「桃浦」においても 2014 年 4 月に第 2 回となる漁業体 験プログラムが開催され, 第 1 回同様, 地域外から多く の参加者が集まった。今後更に「漁業十漁村型」の活動 が地元に根付き継続的に行われ, 漁業復旧にとどまらな い漁村復興に向けた活動が発展していく可能性が高い。

「雄勝」, 「桃浦」は共に, 元々の漁業従事者以外の主 体により「漁業限定型」の活動が「漁業十漁村型」の活 動へと展開されていった事例である。震災前にはあまり みられなかった漁業従事者と漁業従事者以外の主体の連 携による, 漁業復旧にとどまらない漁村復興に向けた活 動の発展の可能性が明らかになった。

\section{V まとめ}

本研究では, 被災漁村において, 震災以前の漁業実態, 震災後の被災・復旧状況, 復興に向けた活動について, 分析指標を重ね合わせることにより, 漁村復興に向けた 動向と課題を考察した。以下に, 結論を示す。

1）被災 95 地区における漁業基盤指標を用い, 震災以前 の漁業体力の実態から5 類型を設定した。また被災 29 市町村における被災・復旧状況についても分析をおこな い, 世界有数の好漁場といわれてきた三陸沿岸部であっ ても, 震災から 3 年経過した現在でも漁業経営再開率は 高くなく, 広範囲で甚大であった事実を改めて検証した。 2) 復旧の第一歩である漁業復旧, 漁村全体の復興に向 けた活動の組み合わせの状況により活動タイプ 4 類型を 設定し, 復興活動における地域外との関係を考察, 震災 以前の漁業体力の大小と, 復興に向けた活動内容との連 関を分析した。「漁業限定型」から「漁業十漁村型」へ の活動発展がみられた双方向型の地区の多くは, 震災以 前に相対的に漁業体力が小さくない地区であった。

3) 2 地区の復興活動調査により,「漁業限定型」から「漁 業十漁村型」 への活動発展の際の漁業従事者以外の多様 な主体との関係性, 地区ごとの特性や効果を分析した。

漁村復興の方向性は一様ではない。今後各漁業地区の
被災状況も合わせて分析することで, 震災以前の実態, 被災状況, 復興に向けた活動の連関に関する詳細な考察 を進めていく予定である。また復興の継続的な進行を目 指す中で, 様々な地区において, 漁業従事者と多様な主 体の関わりや次世代への活動展開等を客観的に分析しつ つ地域の復興に応用出来る知見の抽出を目指す。

本研究は, 【平成 24-28 年度科学研究費 基盤研究 (A)「連携 と持続に着目した東日本大震災の農村復興に関する総合的農村 計画研究」】の環として行っている。

\section{注}

注 1)震災以前の実態については, 漁業センサス $2008^{7)}$ より, 漁業 集落 (476 集落) と漁業地区 (95 地区) ごとのデータが存在し, 両方の分析をおこなった。本稿においては, 漁業地区の定 義「沿岸市区町村等の区域内において共通の漁業条件の下に 漁業が行われる地区として, 共同漁業権を中心とした地先漁 場の利用等漁業に係る社会経済活動の共通性に基づき設定。」 を鑑みた結果，また，震災後さらに，構成する漁家戸数が減 少した集落も多い中，まとまった複数集落が連携して復興を 目指寸場合が多いと考えられること, 等から複数集落の一定 のまとまりである漁業地区を分析単位とした。

注 2)漁業地区の類型化はクラスター分析の結果に基づいておこ ない, クラスターA には漁業規模, 及び漁業活力が相対 的に大きい漁業地区が含まれている。

注 3)経営体被災率 $=($ 被害あり経営体数 / 震災時経営体数 $) \times 100(\%)$ 注 4 )漁船被災率 $=($ 被害あり漁船数 / 震災時漁船数 $) \times 100(\%)$ 注 5)再開率 $=($ 経営再開した経営体数 $/$ 被害あり経営体数 $) \times 100(\%)$ 注 6)C類型は図 5 において原点付近に位置する平均的な值を取る 地区が集まる類型， $\mathrm{E}$ 類型は 4 割超の 42 地区が含まれる漁 業体力が非常に小さい類型であり，その中で漁業復旧にとど まらない復興に向けた活動を行っている地区を選定した。

\section{参考文献}

1) 月舘敏弘 (2012) : 海岸地形に着目した明治以降に三陸沿岸 を襲った主な津波による被害と対策に関する研究; 農村計画 学会東日本大震災復興支援研究報告書 No. 1, pp. 183-188.

2) 富田宏 (2012) : 被災地漁業・漁村再生の展望について - 浜のく らしと生業から見る被災地沿岸漁業と小漁村復旧・再生の課題 -; 農村計画学会東日本大震災復興支援研究報告書 No. 1 pp. 73-82.

3) 三笠友洋 (2012)：被災漁村集落における住まいの特徴と地 域型復興住宅の課題 - 大船渡市三陸町崎浜集落の事例を元 に; 農村計画学会誌 31(3), pp. 490-493.

4) 富田宏 (2014)：東日本漁村復興 3 年目の無力感の本質 - 沈 黙と思考停止からの脱出; 農村計画学会誌 $32-4$.

5) 重村力（2012）：大震災 2 年を経た三陸漁村集落地域の復興 過程の問題点, 農村計画学会東日本大震災復興支援研究報告 書 No. 1, pp. 199-204.

6) 広田純一 (2012) : 東日本大震災の津波被災地における復旧・ 復興の経過と現状の課題 - 岩手県・宮城県を中心に, 震災 8 ケ月後の状況, 農村計画学会誌 30-4, pp. 530-536.

7) 農林水産省 (2008)：漁業センサス 2008 第 4 巻海面漁業に関 する統計 (漁業地区編).

8) 農林水産省：東日本大震災による漁業経営体の被災・経営再 開状況 $\mathrm{H} 23 \cdot \mathrm{H} 24 \cdot \mathrm{H} 25$ 年版.

9) 各市町村 HP : 復興計画 .

10)各活動主体 (漁協, NPO 法人, 社団法人, 株式会社等 ) HP. 11)農林水産省水産庁 (2011) : 平成 23 年度 水産白書

12)佐藤滋 (2011) : 東日本大震災からの復興まちづくり, 大月 書店, 東京.

Summary:Now that three years have passed since the Great East Japan Earthquake, there are the activities of fi shery villages reconstruction through the fi shing industry rebuilt in some. We analised actual situation of fi shery villeges before the earthquake , disaster-recovery situation, activities for reconstruction about fi shery villages of Aomori, Iwate, Miyagi prefecture. The results of the analysis is the status of fi shery villages of before the earthquake is largely responsible for development of activities for reconstruction.

キーワード (Key words) : 漁業集落 (Fishery villeges), 東日本大震災 (The Great East Japan Earthqake), 復興活動 (Reconstraction activities), 漁業センサス (Fisher census) 